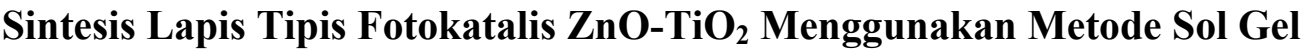 dengan PEG (Polyethylene Glycol) sebagai Pelarut
}

\section{Synthesis Thin Layer ZnO-TiO 2 Photocatalysts Sol Gel Method by Using The PEG (Polyethylene Glycol) as Solvent}

\author{
Tanti Haryati ${ }^{*}$, Novita Andarini, Mellisa Ika Febrianti \\ Jurusan Kimia, Fakultas Matematika dan Ilmu Pengetahuan Alam \\ Universitas Jember \\ ${ }^{*}$ Email: tanti@unej.ac.id
}

\begin{abstract}
The incorporation of $\mathrm{TiO}$ and $\mathrm{ZnO}$ material as a composite, to increase the activity of the catalyst.

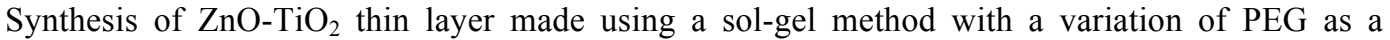
solvent. The purpose of this research was to investigate the structure and morphology of $\mathrm{ZnO}-\mathrm{TiO}_{2}$ thin layer on the variation of PEG as a solvent by sol-gel method. Preparation of $\mathrm{ZnO}$ sol of the precursor, while the $\mathrm{TiO}_{2}$ sol synthesized by dissolving the anatase $\mathrm{TiO}_{2}$ structure into polyethilen glycol . Sol of $\mathrm{ZnO}$ and $\mathrm{TiO}_{2}$ sol do sol mixing to form $\mathrm{ZnO}-\mathrm{TiO}_{2}$ after it coated on a glass substrate and then calcined. Products were then characterized by X-ray diffraction to determine the crystal structure and SEM to determine its morphology . The test results show the crystal structure by XRD based difaktogram intensity, the greater the molecular weight of the PEG peak intensity of $\mathrm{ZnO}-\mathrm{TiO}_{2}$ showed the lower. While based on morphological examination, it can be seen that the larger molecular weight $\mathrm{PEG}, \mathrm{ZnO}-\mathrm{TiO} 2$ granular greater
\end{abstract}

Key words: photocatalyst, $\mathrm{TiO}_{2}$, ZnO, sol-gel, PEG (Polyethylene Glycol), XRD, SEM

\section{PENDAHULUAN}

Fotokatalis adalah suatu proses terjadinya reaksi yang diperantai oleh energi dari penyinaran ultra violet. Semikonduktor oksida logam seperti $\mathrm{TiO}_{2}$ sering digunakan sebagai fotokatalis dalam penanganan limbah organik (Wijaya, 2005). Metode fotokatalisis $\mathrm{TiO}_{2}$ yang banyak digunakan oleh penelitian sebelumnya pada dasarnya memiliki beberapa kelemahan yaitu penggunaan $\mathrm{TiO}_{2}$ serbuk yang kurang efisien yang disebabkan oleh beberapa hal diantaranya, $\mathrm{TiO}_{2}$ serbuk yang telah terdispersi dalam zat warna sulit untuk diregenerasi, turunnya aktivitas $\mathrm{TiO}_{2}$ konsentrasi $\mathrm{TiO}_{2}$ akibat adanya turbulensi (Tian, J, et. al, 2009). Sementara itu $\mathrm{ZnO}$ juga merupakan bahan semikonduktor yang aktif selain $\mathrm{TiO}_{2}$. Semikonduktor $\mathrm{ZnO}$ memiliki beberapa sifat yang menguntungkan yaitu memiliki celah pita yang lebar, spektrum emisi kuat pada suhu kamar dan bersifat tranparan (semikonduktif) jika dikenai sinar, sehingga banyak diaplikasikan sebagai bahan tambahan untuk meningkatkan aktivitas fotokatalis dari $\mathrm{TiO}_{2}$.
Sebagian besar peneliti semikonduktor fotokatalis membuat lapisan tipis semikonduktor pada plat kaca dengan menggunakan metode seperti teknik sol gel (Nasr, et al, 1998).

Penggabungan antara $\mathrm{TiO}_{2}$ dan $\mathrm{ZnO}$ sebagai suatu komposit, untuk meningkatkan aktivitas katalis. Tulisan ini melaporkan hasil penelitian sintesis lapis tipis $\mathrm{ZnO}-\mathrm{TiO}_{2}$ dengan digunakan variasi polietilen glikol. polietilen glycol yang digunakan pada penelitian ini diantaranya PEG 1500, PEG 6000 dan PEG 10000 dengan menggunakan metode sol-gel. Pada penelitian ini menggunakan teknik film tipis dan karakterisasinya menggunakan Scanning Electron Microscopy (SEM) dan Difraksi sinar-X (XRD atau X-ray difraction). Hasil dari sintesis $\mathrm{ZnO}^{-\mathrm{TiO}_{2}}$ dengan variasi polietilen glikol akan dilakukan uji karakterisasi untuk mengetahui struktur dan morfologinya.

Tujuan dari penelitian ini adalah mengetahui struktur dan morfologi dari lapis tipis $\mathrm{ZnO}_{-} \mathrm{TiO}_{2}$ pada variasi PEG sebagai pelarut dengan metode sol-gel. 


\section{METODE}

$\begin{array}{lccc}\text { Sintesis } & \mathrm{TiO}_{2}-\mathrm{ZnO} & & \\ \text { Sintesis } & \mathrm{Zn}\left(\mathrm{CH}_{3} \mathrm{COO}\right)_{2} & 2 \mathrm{H}_{2} \mathrm{O}-\mathrm{TiO}_{2} & \text { diawali } \\ \text { dengan } & \text { pembuatan } & \text { sol } & \mathrm{ZnO},\end{array}$
$\mathrm{Zn}\left(\mathrm{CH}_{3} \mathrm{COO}\right)_{2} .2 \mathrm{H}_{2} \mathrm{O}$ yang dilarutkan kedalam etanol kemudian dilakukan pengadukan pada temperatur $70^{\circ} \mathrm{C}$ dan dilakukan penambahan tetes demi tetes aquades, $\mathrm{NH}_{2} \mathrm{CH}_{2} \mathrm{CH}_{2} \mathrm{OH}$ dan etanol sambil dilakukan pengadukan selama 2 jam hingga terjadi sol ZnO. Sedangkan untuk sol $\mathrm{TiO}_{2}$ yang pertama dilakukan adalah bubuk $\mathrm{TiO}_{2}$ (stuktur anatase) ditambahkan PEG 1500 kemudian ditambahkan etanol, dilarutkan dan diaduk selama 1 jam. Setelah terbentuk sol $\mathrm{ZnO}$ dan sol $\mathrm{TiO}_{2}$ dilakukan pencampuran secara langsung dan dilakukan pengadukan sampai homogen hingga terbentuk sol $\mathrm{ZnO}$ $\mathrm{TiO}_{2}$.

\section{Kalsinasi $\mathrm{TiO}_{2}-\mathrm{ZnO}$}

Pada $\mathrm{TiO}_{2}-\mathrm{ZnO}$ sol yang terbentuk akan dilakukan pelapisan dan pelapisan hanya dilakukan sekali serta dilakukan pengeringan. Sebelum digunakan proses pelapisan kaca tersebut dibersihkan dan dilakukan pemanasan $100^{\circ} \mathrm{C}$ selama 15 menit. Setalah itu dilakukan proses pengeringan pada suhu ruang selama 10 menit.

Langkah berikutnya, film tipis ${\mathrm{ZnO}-\mathrm{TiO}_{2}}_{2}$ dilakukan kalsinasi pada suhu $400^{\circ} \mathrm{C}$ selama 1 jam. Setelah itu, film tipis itu akan di kerinngkan pada temperatur ruang. Selanjutnya sampel film $\mathrm{TiO}_{2}-\mathrm{ZnO}$ dilakukan untuk karakterisasi XRD dan SEM.

\section{HASIL DAN PEMBAHASAN}

Pertumbuhan $\mathrm{ZnO}$ dari prekursor $\mathrm{Zn}\left(\mathrm{CH}_{3} \mathrm{COO}\right)_{2} .2 \mathrm{H}_{2} \mathrm{O}$ menggunakan proses solgel umumnya mengalami empat tahap, yaitu solvasi, hidrolisis, polimerisasi, dan transformasi menjadi $\mathrm{ZnO}$. Prekursor $\mathrm{Zn}\left(\mathrm{CH}_{3} \mathrm{COO}\right)_{2} .2 \mathrm{H}_{2} \mathrm{O}$ terlarut dalam etanol absolut 99,99\%, dan kemudian dihidrolisis, dianggap sebagai penghapusan ion asetat sehingga hasil dalam zink hidroksida berupa koloid-gel. Etanol absolut 99,99 \% dapat lebih mudah bereaksi untuk membentuk prekursor polimer dengan tingkat polimerisasi yang lebih tinggi, sehingga diperlukan untuk mengkonversi sol menjadi gel, ini terbagi menjadi hidroksida seng kation $\mathrm{Zn}^{2+}$ dan anion
$\mathrm{OH}^{-}$menurut reaksi dan diikuti dengan polimerisasi yang kompleks hidroksil untuk membentuk "Zn-O-Zn" dan akhirnya berubah menjadi ZnO (Rani, et al.2008). Mekanisme reaksinya sebagai berikut:

$$
\begin{aligned}
& \mathrm{Zn}\left(\mathrm{CH}_{3} \mathrm{COO}\right)_{2} \cdot 2 \mathrm{H}_{2} \mathrm{O} \stackrel{\mathrm{CH}_{3} \mathrm{CH}_{2} \mathrm{OH}}{\longrightarrow} \mathrm{Zn}^{2+}+2 \mathrm{CH}_{3} \mathrm{COO}^{-}+2 \mathrm{H}_{2} \mathrm{O} \text { Solvasi } \\
& \mathrm{Zn}^{2+}+2 \mathrm{CH}_{3} \mathrm{COO}^{-}+2 \mathrm{H}_{2} \mathrm{O}+\mathrm{NH}_{2} \mathrm{CH}_{2} \mathrm{CH}_{2} \mathrm{OH} \underset{\mathrm{CH}_{3} \mathrm{CH}_{2} \mathrm{OH}}{\stackrel{\text { Aquades }}{\longrightarrow}} \\
& \mathrm{Zn}(\mathrm{OH})_{2}+2 \mathrm{CH}_{3} \mathrm{CH}_{2} \mathrm{COONH}_{4}+\mathrm{H}_{2} \mathrm{O} \quad \text { hidrolisis } \\
& \mathrm{Zn}(\mathrm{OH})_{2}+2 \mathrm{H}_{2} \mathrm{O} \longrightarrow \mathrm{Zn}(\mathrm{OH})_{4}{ }^{2+}+2 \mathrm{H}^{+} \quad \text { polimerisasi } \\
& \mathrm{Zn}(\mathrm{OH})_{4}{ }^{2+} \rightleftharpoons \mathrm{ZnO}+\mathrm{H}_{2} \mathrm{O}+2 \mathrm{OH}^{-} \quad \text { Transformasi }
\end{aligned}
$$

Gambar 1. Reaksi pembentukan $\mathrm{ZnO}$

Pembuatan sol $\mathrm{TiO}_{2}$ ini menggunakan $\mathrm{TiO}_{2}$ anatase bukan dari prekursor. Proses sintesis lapis tipis pada pembuatan sol $\mathrm{TiO}_{2}$ menggunakan $\mathrm{TiO}_{2}$ anatase hal ini dilakukan karena tidak membutuhkan waktu yang lama untuk menghasilkan sol $\mathrm{TiO}_{2}$. Setelah dilakukan pencampuran antara $\mathrm{PEG}, \mathrm{TiO}_{2}$ dan etanol dilakukan pengadukan selama 1 jam sampai terbentuk sol $\mathrm{TiO}_{2}$. Kemudian dilakukan pencampuran antara sol $\mathrm{ZnO}$ dan sol $\mathrm{TiO}_{2}$ tetap dilakukan pemanasan hingga terbentuk sol $\mathrm{ZnO}-\mathrm{TiO}_{2}$. Proses pelapisan $\mathrm{ZnO}$ $\mathrm{TiO}_{2}$ dengan variasi PEG dapat diketahui bahwa pada proses pemanasan setelah dilakukan pencampuran antara sol $\mathrm{ZnO}$ dan sol $\mathrm{TiO}_{2}$ dengan menggunakan pelarut PEG 1500 membutuhkan waktu yang cukup lama sekitar 2 jam untuk membentuk sol $\mathrm{ZnO}-\mathrm{TiO}_{2}$ dan bercak yang dihasilkan setelah proses sol-gel juga kecil dibandingkan sol $\left(\mathrm{ZnO}-\mathrm{TiO}_{2}\right)$ :PEG 6000 dan pada sol $\left(\mathrm{ZnO}^{-\mathrm{TiO}_{2}}\right)$ :PEG 10000. Hal ini di sebabkan karena PEG pada proses kalsinasi hilang dan meninggalkan bercak yang sesuai dengan berat molekulnya, semakin berat molekul PEG besar maka bercak yang ditinggalkan semakin besar.

\section{Struktur dan Morfologi dari ${\mathrm{ZnO}-\mathrm{TiO}_{2}}_{2}$ Struktur Kristal ZnO-TiO}

Salah satu metode yang digunakan dalam penentuan struktur kristal $\mathrm{ZnO}-\mathrm{TiO}_{2}$ adalah metode difraksi sinar-X. Metode difraksi sinar$\mathrm{X}$ digunakan untuk mengetahui struktur dari 
$\mathrm{ZnO}-\mathrm{TiO}_{2}$ yang terbentuk dengan meletakkan lapis tipis $\mathrm{ZnO}-\mathrm{TiO}_{2}$ pada holder difraktometer sinar-X. Hasil difraksi sinar-X pada $\mathrm{ZnO}-\mathrm{TiO}_{2}$ menunjukkan bahwa titanium yang digunakan adalah polikristal dengan struktur anatase sintetis. Pola difraksi sinar-X polikristal $\mathrm{TiO}_{2}-$ $\mathrm{ZnO}$ diperoleh dari difraktometer sinar-X dengan radiasi $\mathrm{CuK}_{\alpha}(\lambda=1.54056 \AA \hat{)})$. Pengukuran dilakukan pada daerah $2 \theta=10^{\circ}-$ $90^{\circ}$. Beda potensial dan arus listrik yang digunakan pada difraktometer sinar- $\mathrm{X}$ sebesar $40 \mathrm{kV}$ dan $30 \mathrm{~mA}$.

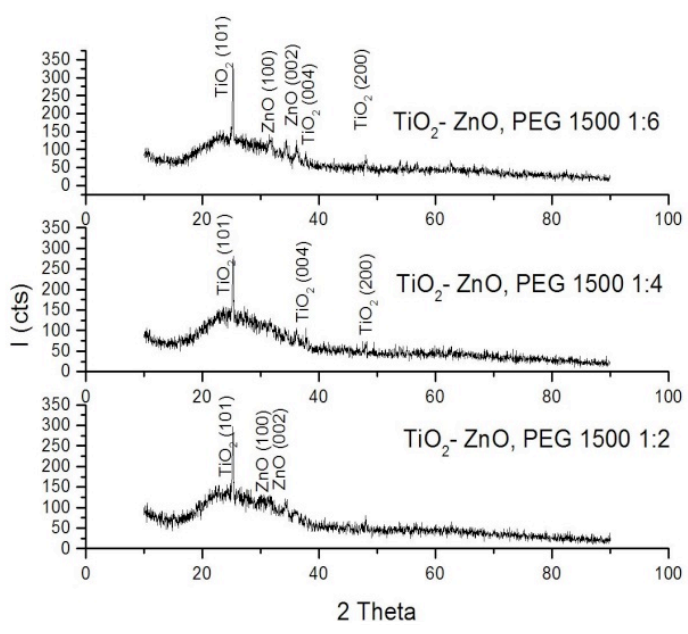

Gambar 2. Difraktogram fotokatalis $\mathrm{TiO}_{2}-\mathrm{ZnO}$ (PEG 1500)

Data difraktogram pada Gambar 2 yang diperoleh dapat disimpulkan pembentukan produk dalam hal ini yaitu $\mathrm{ZnO}-\mathrm{TiO}_{2}$ yang paling bagus pada sintesis adalah pada $\left(\mathrm{TiO}_{2}-\right.$ $\mathrm{ZnO})$ :PEG 1500 dengan perbandingan 1:6, yang dibuktikan dengan pola difraksi yang paling tinggi intensitasnya dan paling tajam puncaknya. Hal ini dikarenakan pembentukan sintesis lapis tipis mendekati sempurna sedangkan pada $\left(\mathrm{TiO}_{2}-\mathrm{ZnO}\right)$ :PEG 1500 dengan perbandingan 1:2 dan 1:4. Karena menghasilkan ukuran kristal yang paling kecil,

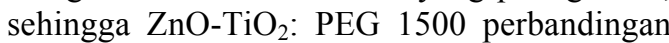
1:6 selanjutnya dilakukan uji SEM untuk menganalisa morfologinya.

Hasil difraktogram pada difraksi sinar-X dari fotokatalis $\left(\mathrm{ZnO}-\mathrm{TiO}_{2}\right)$ : PEG 6000 dapat dilihat pada Gambar 3.

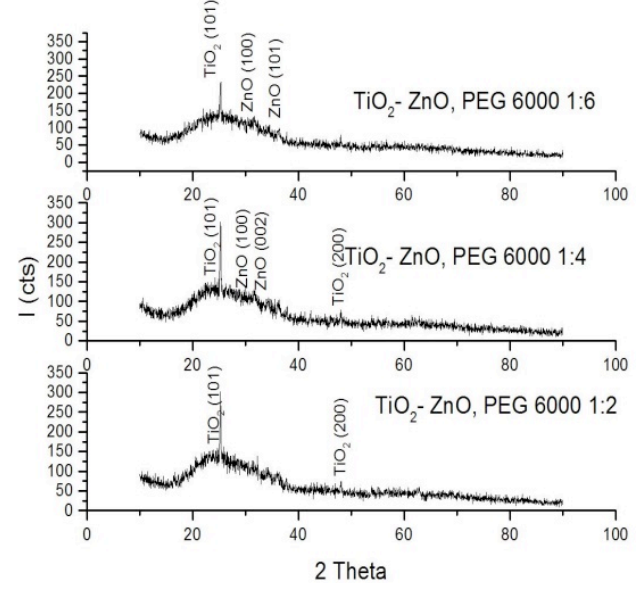

Gambar 3 Difraktogram fotokatalis $\mathrm{TiO}_{2}-\mathrm{ZnO}$ (PEG 6000)

Hasil karakterisasi XRD dari fotokatalis $\mathrm{ZnO}-\mathrm{TiO}_{2}$ dengan PEG 6000 yang disintesis dan di kalsinasi suhu $200 \cdot \mathrm{C}-400 \cdot \mathrm{C}$ membuktikan adanya kristal $\mathrm{ZnO}-\mathrm{TiO}_{2}$. Hal ini dapat ditunjukkan dengan puncak yang muncul pada difraktogram XRD seperti yang terlihat pada gambar 3. Pola difraksi $\left(\mathrm{TiO}_{2}-\mathrm{ZnO}\right)$ :PEG 6000 pada perbandingan 1:2 ini tidak ditemukan puncak dari $\mathrm{ZnO}$ hanya ditemukan puncak dari $\mathrm{TiO}_{2}$. Sedangkan pada difraktogram $\quad\left(\mathrm{TiO}_{2}-\mathrm{ZnO}\right)$ :PEG 6000 perbandingan 1:4 dan $\left(\mathrm{TiO}_{2}-\mathrm{ZnO}\right)$ :PEG 6000 perbandingan 1:6 diketahui puncak dari $\mathrm{ZnO}$ $\mathrm{TiO}_{2}$.

Gambar 3 difraktogram fotokatalis dapat disimpulkan bahwa pembentukan produk dalam hal ini yaitu $\mathrm{ZnO}-\mathrm{TiO}_{2}$ yang paling kristalin adalah pada difraktogram $\left(\mathrm{TiO}_{2-}\right.$ $\mathrm{ZnO}$ ):PEG 6000 dengan perbandingan 1:4 yang dibuktikan dengan pola difraksi yang paling tinggi intensitasnya dan paling tajam puncaknya. selanjutnya pada difraktogram $\left(\mathrm{TiO}_{2}-\mathrm{ZnO}\right)$ :PEG 6000 dengan perbandingan 1:4 akan dilakukan analisa morfologinya dengan menggunakan Scanning Electron Microscopy (SEM).

Difraktogram dari fotokatalis $\left(\mathrm{ZnO}-\mathrm{TiO}_{2}\right)$ : PEG 10000 dapat diketahui pada difraktogram dari hasil difraksi sinar-X sebagaimana pada Gambar 4. 


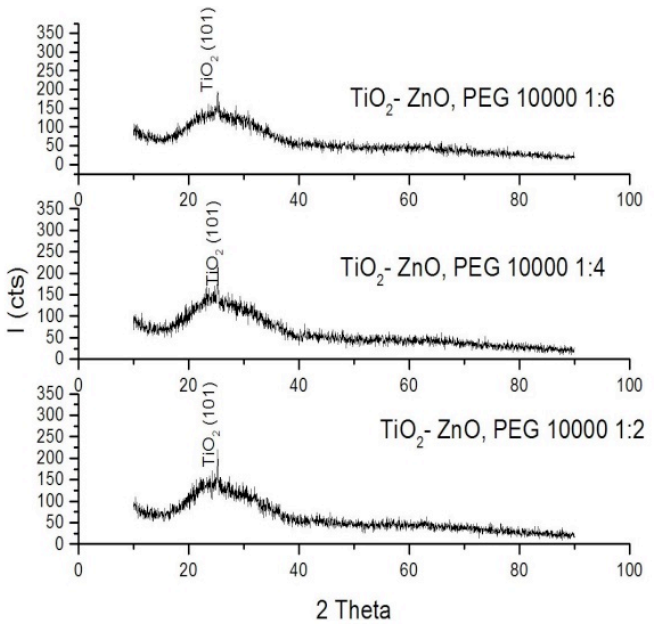

Gambar 4 Difraktogram fotokatalis $\mathrm{TiO}_{2}-\mathrm{ZnO}$ (PEG 10000)

Difraktogram $\quad\left(\mathrm{TiO}_{2}-\mathrm{ZnO}\right): \mathrm{PEG} \quad 10000$ dengan perbandingan 1:2,1:4 dan 1:6 seperti yang terlihat pada gambar 4 hanya diperoleh $\mathrm{TiO}_{2}$ anatase pada $2 \theta: 25,2336^{\circ} ; 25,2487^{\circ}$ dan $25,2349^{\circ}$. ZnO tidak ditemukan pola difraksi yang paling tinggi intensitasnya dan paling tajam puncaknya, hal ini disebabkan adanya butiran kristal $\mathrm{ZnO}$ yang terbentuk sedikit. Oleh karena itu semakin besar berat molekul PEG 10000, semakin panjang rantai pada PEG 10000 menyebabkan semakin banyak partikel $\mathrm{ZnO}$ yang terjebak di dalam rantai PEG sehingga pertumbuhan kristal terbatasi atau terhalangi dan butiran kristal $\mathrm{ZnO}$ sulit berinteraksi pada PEG karena pori PEG 10000 lebih besar dari pada diameter $\mathrm{ZnO}$, sehingga butiran kristal $\mathrm{ZnO}$ yang terdapat di PEG 10000 tidak terdeteksi oleh difraktogram fotokatalis menggunakan sinar-X tetapi pada $\mathrm{TiO}_{2}$ terdapat puncak yang terlihat pada difraktogram sinar-X, hal ini dikarenakan $\mathrm{TiO}_{2}$ sudah berupa anatase.

\section{Morfologi ZnO-TiO}

Hasil XRD yang diperlihatkan pada gambar 2 sampai dengan 4 tidak menunjukkan perbedaan yang signifikan pada struktur kristalnya, akan tetapi pada gambar SEM sampel $\mathrm{ZnO}-\mathrm{TiO}_{2}$ yang divariasi berdasarkan PEG yang digunakan menunjukkan perbedaan morfologi seperti yang ditunjukkan pada gambar 5 .

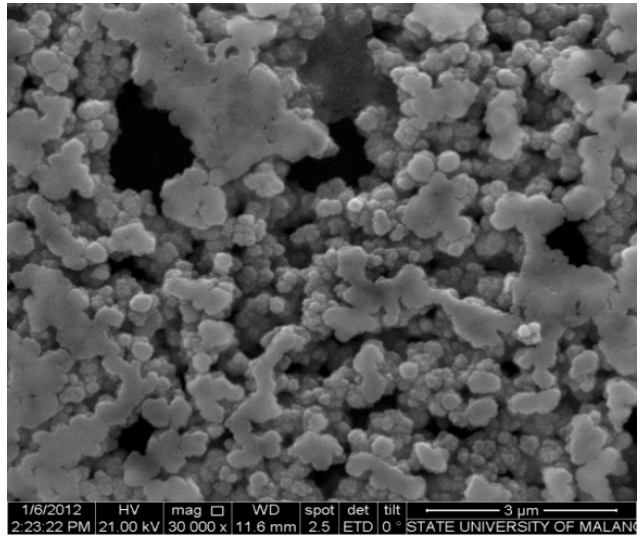

(a)

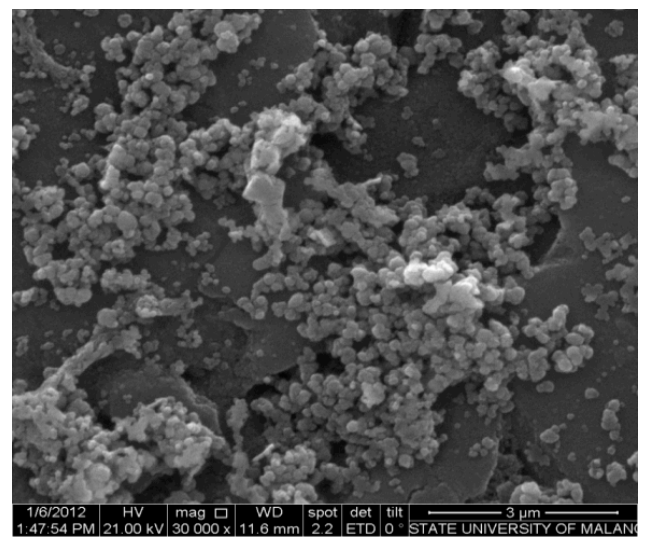

(b)

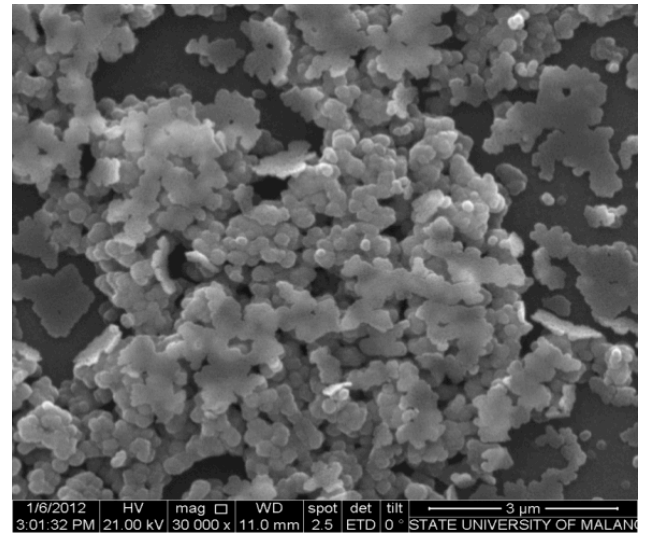

(c)

Gambar 5. Morfologi butiran $\mathrm{TiO}_{2}-\mathrm{ZnO}$ dengan pembesaran 30000 kali [a]. $\left(\mathrm{TiO}_{2}-\mathrm{ZnO}\right)$ :PEG 1500 dengan perbandingan 1:6; [b]. $\left(\mathrm{TiO}_{2}-\mathrm{ZnO}\right)$ : PEG 6000 dengan perbandingan 1:4; [c].( $\left.\mathrm{TiO}_{2}-\mathrm{ZnO}\right):$ PEG 10000 dengan perbandingan 1:4 
Gambar 5 dapat dilihat morfologi antara $\left(\mathrm{TiO}_{2}-\mathrm{ZnO}\right): \mathrm{PEG} 1500$ perbandingan 1:6, $\left(\mathrm{TiO}_{2}-\mathrm{ZnO}\right)$ :PEG 6000 perbandingan 1:4, dan $\left(\mathrm{TiO}_{2}-\mathrm{ZnO}\right)$ :PEG 10000 dengan perbandingan 1:4 memiliki bentuk morfologi yang berbedabeda. Hal ini dikarenakan semakin besar berat molekul PEG, semakin banyak jumlah partikel zat terlarut dalam volume tertentu, sehingga mengakibatkan semakin besar butiran kristal dan susunan yang semakin teratur, sedangkan pori yang dihasilkan semakin besar. Sedangkan PEG 10000 mempunyai rantai yang lebih panjang dibanding PEG 1500 dan 6000 . Panjang rantai ini menyebabkan semakin banyak partikel $\left(\mathrm{TiO}_{2}-\mathrm{ZnO}\right)$ yang terjebak di dalam rantai $P E G$ sehingga pertumbuhan kristal terbatasi atau terhalangi, karena pertumbuhanya terhambat, ukuran kristal $\left(\mathrm{TiO}_{2}-\mathrm{ZnO}\right)$ semakin kecil.

\section{KESIMPULAN}

Berdasarkan hasil penelitian yang telah dilakukan dapat diambil kesimpulan bahwa berdasarkan intensitas difaktogram, semakin besar berat molekul PEG maka intensitas puncak $\mathrm{ZnO}-\mathrm{TiO}_{2}$ semakin rendah dan pola difraksi yang didapatkan juga semakin rendah. Berdasarkan morfologi lapis tipis $\mathrm{ZnO}-\mathrm{TiO}_{2}$, dapat diketahui bahwa semakin besar berat molekul PEG maka dihasilkan semakin besar butiran kristalin $\mathrm{ZnO}-\mathrm{TiO}_{2}$, dan pori-pori yang semakin besar.

\section{DAFTAR PUSTAKA}

Nasr, C., Vinodgopal., K., Fisher, L., Hotchandani, S., Chattopadhay, A. K., and Kamat, P.V. 1999. Enviromental Photochemistry on Semiconductor Surface.Visible Light Induced Degradation of a Textile Diazo Dye, Naphthol Blue Black on $\mathrm{TiO}_{2}$ Nanoparticles, J. Phys. Chem. 100, 8436-8442.

Rani, S., Suri, P., Shishodia, P.K., Mehra, R.M., 2008. Synthesis Of Nanocrystalline Powder Via Sol-Gel Route For Dye-Sensitized Solar Cells. Solar Energy Materials and Solar Cells, 92(12), 1639-1645.

Tian, J., Chen, L., Yin, Y., Wang, X., Dai, J., Zhu, Z., Liu, X., Pingwei, W. 2009. Photocatalyst Of $\mathrm{TiO}_{2} / \mathrm{ZnO}$ Nano Composite Film: Preparation, Characterization, and Photodegradation Activity Of Methyl Orange. Surface and Coatings Technology, 204(1-2), 205-214.

Wijaya K. 2005. Sintesis $\mathrm{TiO}_{2}$-Zeolit sebagai Fotokatalis pada Pengolahan Limbah Cair Industri Tapioka Secara Adsorpsi-fotodegradasi. TEKNOIN, 10(4), 257-267. 